\title{
Effects of recharge area and drainage system on ground water quality of Telkaif area/ north of Iraq
}

\author{
Taha Hussein Al-Salim ${ }^{1}$, Asmaa Khalid Jarjees ${ }^{1}$ \\ ${ }^{1}$ Remote Sensing Center, Depatment of Geography, University of Mosul, Irag
}

Rec. 12 May, 2011 Accpt. 17 Jun, 2011

\begin{abstract}
:
Drainage system and recharge area of the catchment area plays important role in recharging ground water aquifer, through infilteration of rain and runoff water to the ground water depending on the type of sediments cover, intensity of rainfall, slope and intensity of runoff. This study discuss the drainage system recharge and its effect on the concetration of the chemical constituents of ground samples, through the analysis of chemical and physical parameters of ground water samples of the studied area for two periods during the year 2007. The first period of sampling is on April 2007 where the ground water table is on the highest level, while the second period is on November 2007 where the ground water table is on the lowest level. The chemical parameters analyzed were $\mathrm{pH}$, TDS, EC, TH, Ca, Mg, Na, K, $\mathrm{HCO} 3, \mathrm{SO} 4, \mathrm{Cl}$ and $\mathrm{NO} 3$. Chemical parameters such as sodium percentage ( $\mathrm{Na} \%)$, Sodium adsorption ratio (SAR), Permeability Index (PI) and saturation index with respect to calcite and gypsum (SI) were calculated, based on the major cation and anions analysis of ground water samples. A notable variation in the chemical composition of ground water samples between the two analyses has attracted attention of the authors. An attempts is made to interpret the variation in the chemical composition of ground water and the cause of the variation by the interaction of ground water and host rocks in one hand and drainage system recharge and dissolution of surface pollutants during infilteration and percolation of rainwater in the other hand. The abundance of the major ions of the ground water samples $(1,2,3,4)$ is in the following order: $\mathrm{Na}>\mathrm{Ca}>\mathrm{Mg}>\mathrm{K}=\mathrm{HCO} 3>\mathrm{SO} 4>\mathrm{Cl}>\mathrm{NO} 3$, while the abundance of the major ions of the rest samples is in the following order: $\mathrm{Ca}>\mathrm{Na}>\mathrm{Mg}>\mathrm{K}=\mathrm{SO} 4>$ $\mathrm{HCO} 3>\mathrm{Cl}>\mathrm{NO} 3$
\end{abstract}

Key words: Chemical and physical parameters, drainage system, ground water.

\section{Introduction:}

Drainage system recharge has a significante role in the chemical composition of ground water due to the mixing of surface pollutants during infilteration and percolation of rainwater and interaction between ground water flow and hostrocks.

In recent time, there has been a tremendous increase in demand for ground water in the studied area due to the population grow and intense agricultural activities.

Very useful hydrogeological data, such as lithological units of deep well, water level depth and geological prospecting, were obtained.

Geological and agricultural consumers are supplied with water from aquifers, 120 to 180 meter deep. These aquifers consist of Injana and Al-Fatha Formations and forms the only sources of ground water in the area.

The quality of ground water is not uniform and differs from season to another due to the difference in rainfall quantity, recharge, fluctuation change of water level and dissolution between ground water and gypsum.

Rainfall is the main sources of recharging the ground water of the studied area. Different factors affect recharge precipitation, among of these are elevation, time, type and intensity of rainfall. The amount of precipitation increase with altitude. Short and heavy rainfalls are directly affect the recharge in the area due to the high permeable soil covered.

The depth to the ground water level of deep wells in the studied area range between 6-10 meter during rainy season, while in dry season range between 10-14 meter.

People in the studied area abstracted water from deep wells to meet their needs and domestic purposes. It is not an exaggeration that the number of wells drilled during the last five years is more than the number of

\footnotetext{
* Corresponding author:

Dr. Taha Hussein Al-Salim

凶taha al-salim@yahoo.com
} 
wells drilled in the studied area since its existence.

In order to know the effects of drainage system recharge on ground water quality; a study of quality variation of the ground water in the studied area were carried out through the analysis of (10) samples from deep wells of the studied area, for two periods during the year 2007. The data were used to determine water quality and as an information for assesment of the drainage system recharge and water bearing rock influence on the chemical cinstituents of the abstracted water.

The authors have referred several aspects of chemical data and discussed the principle characteristics of ground water quality classifications for domestics and irrigation purposes.

\section{Material and Methods:}

Location and description of study area:

The study area is situated in the Northern part of Mosul city covering an area of about $140 \mathrm{Km} 2$ and lacated approximately between

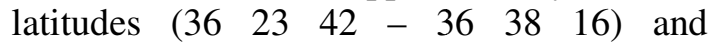
longitudes (42 4419 - 4318 24) Fig. (1). The average elevation for the study area is $380 \mathrm{~m}$. Above sea level. The climate is considered to be semi-arid and the annual precipitation being approximately between $(320-400) \mathrm{mm} .90 \%$ of the total rainfall occurs from Oct.- April. The area is characterized by well-developed dendritic type of drainage system. Tributaries are consider to be non-perenial, as it carries water during rainy season and rainfall of high intensity and long duration. Coarse textured patterns noticed in the plains indicating high rainfall infilteration. The regional slope of the studied area is towards the south where the Tigris River. The most important activity of the area is agriculture, and the cheif crops are wheat, barley, lentil and chick-pea.

\section{Samples collection:}

Water for chemical analysis was sampled directly from the suction pipe of (10)

Wells for water supply. The first period collection of ground water samples are during April 2007 whenever the ground water table is of high level, while the second period of samples collection are during Nov. 2007 whenever the ground water table is of low level. Ground water samples for both periods were analyzed in the laboratories of the Dept. Of geology and Environmental Research Center of Mosul university, for the major ion chemistry employing standards methods (Hem, 1985). The total dissolved solid (TDS) Estimated by residue on evaporation method. The $\mathrm{pH}$ and $\mathrm{Ec}$ were

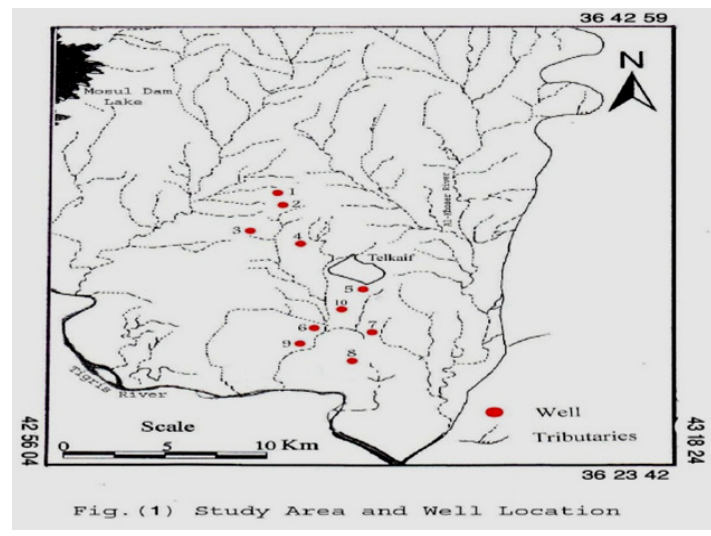

measured using $\mathrm{pH}$ an $\mathrm{Ec}$ meters. $\mathrm{Ca}$ and $\mathrm{Mg}$ were determined titrimetrically using standard EDTA. Chloride $(\mathrm{Cl})$ was determined by standard $\mathrm{AgNO} 3$ titration. Carbonate (CO3) and Bicarbonate (HCO3) were determined by titration with $\mathrm{HCl}$. Na ands $\mathrm{K}$ were measured by flame photometer. SO4 and NO3 were determined by spectrophotometric techniques. The major ion concentration, physical properties and chemical parameters indices for ground water samples of the study area of both periods of the year 2007 are listed in table ( $1 \mathrm{a}$ and $\mathrm{b}$ ) and ( $2 \mathrm{a}$ and $\mathrm{b}$ ).

\section{Results and Discussion: Drainage system:}

A map of the drainage system for the studied area has been prepared Fig. (2). The drainage system, which develops in an area is strictly dependent on the slope, the nature and attitude of bedrock and on the regional and local fractures pattern. Drainage system can be described in terms of pattern types and texture or density of dissection.

The studied area is charcterised by welldeveloped dendritic type of drainage system. Dendritic type is found in homogeneous rock such as soft sedimentary. Drainage system can also be described in terms of texture, and on this basis three types can be recognized:

1- Fine, which is expressive of high run off and impervious bedrock.

2- Medioum, which can be correlative to a medium and mixed lithology. 
3- Coarse, which is available in the studied area. This type is characterized by little run off and coarse permeable soil materials.

4- Structure and lithology seems to be dominant factors in the development of the drainage system which can be of great value for ground water resources.

\section{Geology setting:}

Stratigraphically, the area under research is dominated by geological formations ranging from Middle Miocene to Quaternary as shown in Fig. (3), and as follows:

1- Al Fatha Formation of Middle Miocene:-

This formation is cropped out at the southern part of the studied area and composed of gypsum, anhydrite, marl, clay, green marl and lime stone (Buday and Jassim, 1984; Mohi addin, et al., 1977). The thickness average about (50-75) $\mathrm{m}$.

2- Injana Formation of Upper Miocene:-

This formation crop out at the North East of the study area, composed of sand stone, marl, lime stone and thick beds of red to brown sand stone (Buday and Jassim, 1984).

3- Quaternary sediments:-

The Quaternary sediments are mostly covering the total area under study. This sediments include residual soil (sandy and loamy soil) and flood plain deposits which consist of sand, silt and clay, and slope deposits which consist of rock fragments, sand and silt which is slightly cemented. The thickness varies greatly from less than $2 \mathrm{~m}$. to over $5 \mathrm{~m}$.

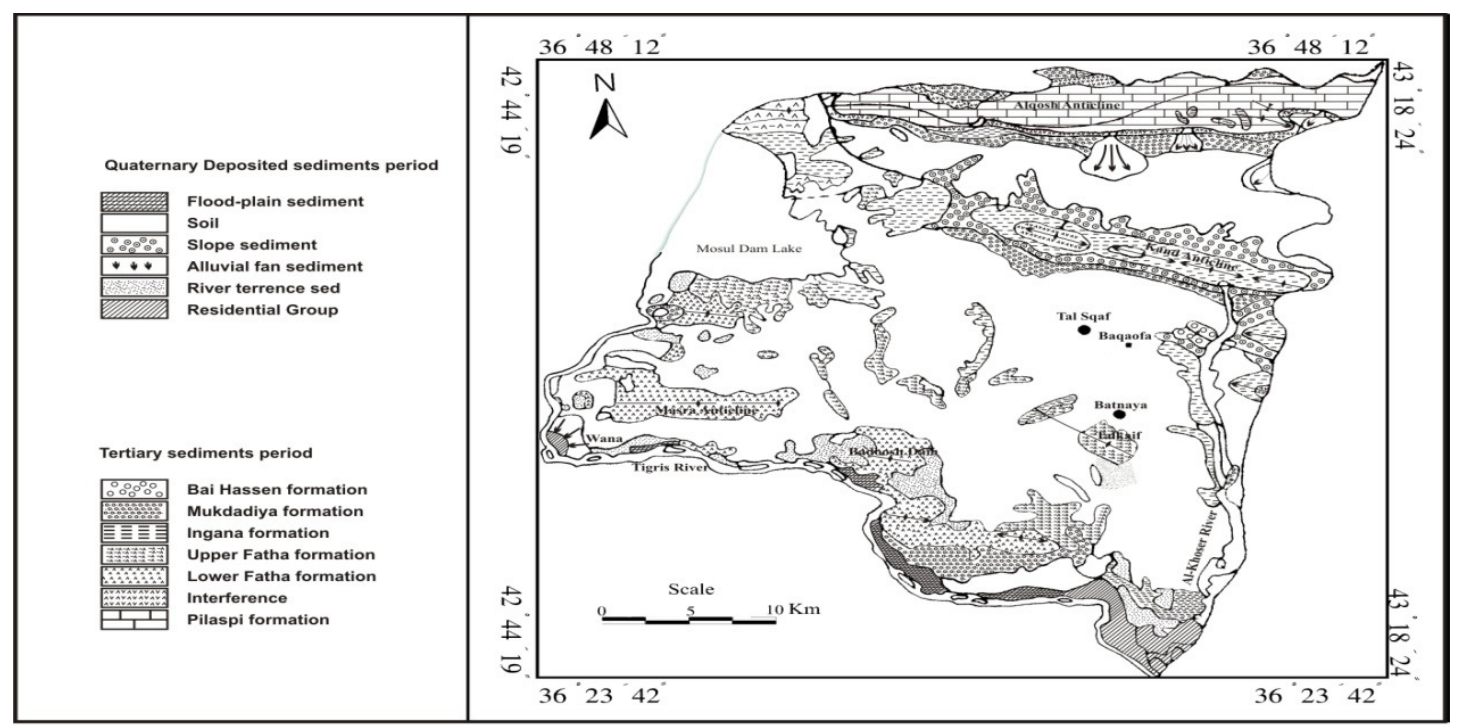

Fig. (2) Geology of the study area

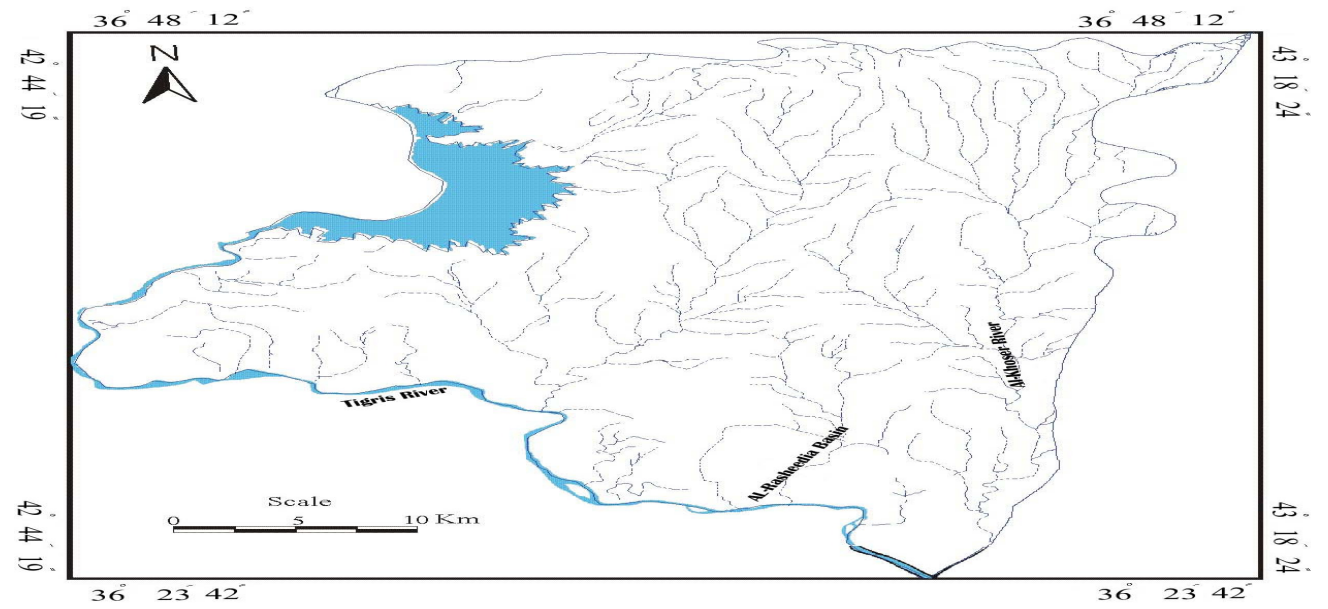

Fig. (3) Drainage System of The Study Area. 


\begin{tabular}{|c|l|l|l|l|l|l|l|l|l|l|l|}
\hline $\begin{array}{c}\text { Well } \\
\text { No. }\end{array}$ & Na & K & Ca & Mg & HCO3 & SO4 & Cl & NO3 & pH & EC & TDS \\
\hline 1 & 110.3 & 3.1 & 100.7 & 92.5 & 448.0 & 206.5 & 88 & 43 & 7.7 & 1365 & 1270 \\
\hline 2 & 108.2 & 2.8 & 99.6 & 97.3 & 470.0 & 223.4 & 69 & 38 & 7.5 & 1415 & 1300 \\
\hline 3 & 112.0 & 2.1 & 110.6 & 95.4 & 442.8 & 210.4 & 74 & 40 & 7.6 & 1390 & 1275 \\
\hline 4 & 124.8 & 2.0 & 115.5 & 108.0 & 492.2 & 236.6 & 76 & 42 & 7.8 & 1425 & 1320 \\
\hline 5 & 82.0 & 3.6 & 258.5 & 125.7 & 420.7 & 1040.0 & 85 & 39 & 7.5 & 2425 & 2235 \\
\hline 6 & 95.0 & 3.2 & 288.7 & 130.8 & 540.3 & 980.0 & 92 & 36 & 7.8 & 2480 & 2350 \\
\hline 7 & 107.0 & 2.9 & 276.4 & 148.2 & 390.5 & 1120.0 & 80 & 34 & 7.4 & 2515 & 2480 \\
\hline 8 & 87.0 & 3.4 & 320.6 & 163.4 & 425.0 & 1180.0 & 78 & 38 & 7.5 & 2500 & 2485 \\
\hline 9 & 93.0 & 3.8 & 238.2 & 172.0 & 475.1 & 850.0 & 90 & 45 & 7.8 & 2275 & 2150 \\
\hline 10 & 88.0 & 3.8 & 340.1 & 152.3 & 365.4 & 1260.0 & 98 & 43 & 7.4 & 2580 & 2520 \\
\hline
\end{tabular}

Table (1a) Concentration Of Chemical Constituents Of Ground Water Samples (ppm) of the period April 2007.

\begin{tabular}{|l|l|l|l|l|l|l|}
\hline $\begin{array}{l}\text { Well } \\
\text { No. }\end{array}$ & TH & Na\% & SAR & PI & SI Ca & SI SO4 \\
\hline 1 & 632.0 & 27.9 & 1.91 & 44.2 & 1.34 & 0.24 \\
\hline 2 & 649.1 & 27.0 & 1.85 & 43.8 & 1.05 & 0.31 \\
\hline 3 & 668.7 & 26.9 & 1.88 & 44.0 & 1.36 & 0.28 \\
\hline 4 & 732.8 & 27.3 & 2.00 & 44.6 & 1.27 & 0.29 \\
\hline 5 & 1162.7 & 12.9 & 1.01 & 25.1 & 0.45 & 1.40 \\
\hline 6 & 1259.1 & 14.4 & 1.16 & 26.3 & 0.32 & 1.63 \\
\hline 7 & 1300.0 & 15.4 & 1.29 & 25.4 & 0.64 & 1.75 \\
\hline 8 & 1472.9 & 11.6 & 0.98 & 22.8 & 0.37 & 1.38 \\
\hline 9 & 1302.5 & 9.4 & 0.72 & 24.5 & 0.26 & 1.64 \\
\hline 10 & 1475.9 & 8.7 & 0.99 & 23.0 & 0.18 & 1.42 \\
\hline
\end{tabular}

Table (1b) Chemical Parameters of Ground Water Samples of the period April 2007.

\begin{tabular}{|c|l|c|c|c|c|c|c|c|c|c|c|c|}
\hline $\begin{array}{c}\text { Well } \\
\text { No. }\end{array}$ & Na & K & Ca & Mg & HCO3 & SO4 & Cl & NO3 & pH & EC & TDS \\
\hline 1 & 97.3 & 2.9 & 92.4 & 88.3 & 435 & 198.0 & 76 & 40 & 7.25 & 1265 & 1120 \\
\hline 2 & 100.5 & 2.8 & 92.2 & 94.6 & 462 & 212.0 & 65 & 32 & 7.38 & 1310 & 1200 \\
\hline 3 & 98.6 & 2.1 & 98.2 & 88.0 & 428 & 198.5 & 68 & 36 & 7.18 & 1280 & 1180 \\
\hline 4 & 102.3 & 2.0 & 100.6 & 98.2 & 478 & 218.0 & 71 & 38 & 7.26 & 1350 & 1220 \\
\hline 5 & 78.7 & 3.4 & 228.7 & 119.4 & 408 & 990.0 & 79 & 35 & 7.45 & 2250 & 2125 \\
\hline 6 & 82.4 & 3.2 & 253.2 & 122.0 & 532 & 930.0 & 84 & 30 & 7.30 & 2280 & 2200 \\
\hline 7 & 91.2 & 2.7 & 238.3 & 136.7 & 378 & 1035.0 & 73 & 29 & 7.55 & 2240 & 2175 \\
\hline 8 & 76.8 & 3.2 & 286.4 & 147.6 & 418 & 1120.0 & 71 & 32 & 7.45 & 2340 & 2280 \\
\hline 9 & 81.5 & 3.7 & 214.5 & 164.8 & 476 & 775.0 & 82 & 38 & 7.35 & 2175 & 2010 \\
\hline 10 & 82.4 & 3.6 & 275.7 & 138.6 & 355 & 1195.0 & 88 & 36 & 7.24 & 2380 & 2275 \\
\hline
\end{tabular}

Table (2a) Concentration Of Chemical Constituents Of Ground Water Samples (ppm) of the period Nov. 2007.

\begin{tabular}{|l|l|l|l|l|l|l|}
\hline $\begin{array}{l}\text { Well } \\
\text { No. }\end{array}$ & TH & Na\% & SAR & PI & SI Ca & SI SO4 \\
\hline 1 & 632.0 & 27.9 & 1.91 & 42.8 & 1.26 & 0.32 \\
\hline 2 & 649.1 & 27.0 & 1.85 & 42.6 & 1.15 & 0.34 \\
\hline 3 & 668.7 & 26.9 & 1.88 & 41.8 & 1.28 & 0.37 \\
\hline 4 & 732.8 & 27.3 & 2.00 & 41.4 & 1.16 & 0.27 \\
\hline 5 & 1162.7 & 12.9 & 1.01 & 23.9 & 0.39 & 1.39 \\
\hline 6 & 1259.1 & 14.4 & 1.16 & 24.9 & 0.28 & 1.58 \\
\hline 7 & 1300.0 & 15.4 & 1.29 & 23.8 & 0.54 & 1.78 \\
\hline 8 & 1472.9 & 11.6 & 0.98 & 20.3 & 0.32 & 1.42 \\
\hline 9 & 1302.5 & 9.4 & 0.72 & 22.8 & 0.21 & 1.68 \\
\hline 10 & 1475.9 & 8.7 & 0.99 & 20.9 & 0.13 & 1.62 \\
\hline
\end{tabular}

Table (2b) Chemical Parameters of Ground Water Samples of the period Nov. 2007. 


\section{Hydrogeology Setting:}

According to the geological formation, two types of aquifers are of particular importance in the study area:

1- Unconfined aquifer, mainly in the Quaternary sediments which has wide geographical distribution and of thickness ranges from 3 to $6 \mathrm{~m}$. This aquifer is underlined by the Pliocene clay which act as a confining bed. The main source of recharge to this aquifer takes place from direct rainfall and wadis runoff.

2- Injana and Al-Fatha formations are considered to be a semiconfined aquifers. Bore hole lithology records as shown in fig. (5) reveal that both formations are separated from Quaternary sediments by an aquiclude of clay sediments in some places, and are hydraulically connected with Quaternary sediments in others. These aquifers consist mainly of variable lithological units of permeable and impermeable beds and receives its water mainly by underflow and leakage from upper regional aquifer. These aquifers are well jointed and fissured and in local scale exhibits solution channels.

Rainfall is the main source of aquifer recharge. It occurs along Quaternary sediments. In addition, infilteration from intermittent tributaries that drai water during period of heavy precipitation.

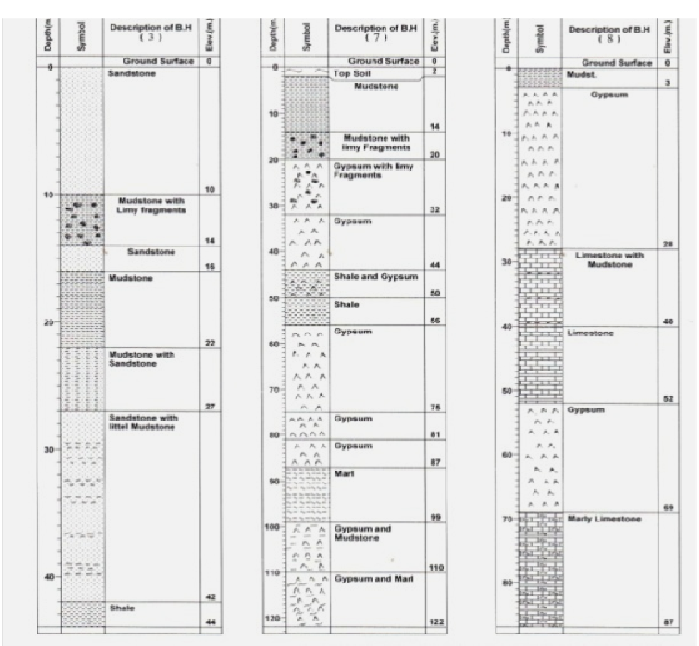

Fig.4 Bore hole litho logical unit

\section{Hydrochemistry:}

The dissimilar composition of ground water type result from numerous hydro chemical processes, among of these processes is the interaction between ground water and host rocks. The concentration of dissolved ions in ground water samples are generally governed by lithology, velocity and quantity of ground water flow, nature of geochemical reactions, solubility of salts and human activities ( Karanth, 1997; Bhatt and Saklani, 1996).

The total dissolved solids (TDS) of ground water analysis is found on the higher side level by comparing with the specification of (TDS) values set up by the WHO (1984). The excess of TDS in the analysis is caused by mixing of surface pollutants during the infiltration and percolation of rainwater downward and the interaction between the ground water and host rocks, and leaching back of salts withhold in the pores of sediments, while ground water evaporated, to the ground water during the rainy period.

The electrical conductivity (EC) make a sign of the amount of salts dissolved in water and its value of ground water samples range from $1930 \mu$ mhos to $4320 \mu$ mohs.

The $\mathrm{pH}$ value of ground water samples in the study area fluctuate within the narrow limits between 7.4 and 7.8. for April 2007 and between 7.18 and 7.55 for the period Nov. 2007.

\section{Sodium Adsorption Ratio (SAR):}

SAR is an important parameter for determining the suitability of ground water for irrigation because it is a measure of alkali/sodioum hazaed to crops. The SAR can be estimated by the formula:

$$
S A R=\frac{N a^{+}}{\left(\mathrm{Ca}^{2+}+\mathrm{Mg}^{2+}\right)^{\frac{1}{2}} / 2}
$$

Where all ionic concentration expressed in epm.

The SAR value of ground water samples range from 2.88 to 6.82 which is fell in the low sodium class. This implies that no alkali hazard to the crops (Saleh et al., 1999). 


\section{Sodium percentage ( $\mathrm{Na} \%)$ :}

Sodium concentration is important in classifying irrigation water because sodium reacts with soil to reduce its permeability. Sodium content is usually expressed in terms of percent sodium $(\mathrm{Na} \%)$. The $\mathrm{Na} \%$ values of ground water samples range from 29.37 to 46.07. The sodium percentage $(\mathrm{Na} \%)$ is calculated using the following formula:

$$
\mathrm{Na} \%=\frac{\left(\mathrm{Na}^{+}+K^{+}\right)}{\left(\mathrm{Ca}^{2+}+M g^{2+}+N a^{+}+K^{+}\right)} * 100
$$

Where all the concentration are expressed in $\mathrm{meq} / \mathrm{l}$.

The Na\% of samples $(2,3,4,5,9,10)$ indicates that the ground water is good for irrigation while samples $(1,6,7,8)$ are permissible (Ragunath, 1987).

\section{Residual Sodium Carbonate (RSC):}

The excess sum of carbonate and bicarbonate in ground water over the sum of calcium and magnesium also influence the unsuitability of ground water for irrigation. This is denoted residual sodium carbonate (RSC), which is determined by the formula (Ragunath, 1987):

$$
\mathrm{RSC}=(\mathrm{HCO} 3=\mathrm{CO} 3)-(\mathrm{Ca}+\mathrm{Mg})
$$

Where the concentration of cations and anions are expressed in epm.

From the residual sodium carbonate value of the ground water samples of the study area, it is observed that all samples are safe for irrigation according to the US Salinity Laboratory Diagram (1954), which is proposed that water containing less than 1.25 $\mathrm{meq} / \mathrm{l}$ is safe for irrigation.

\section{Permeability Index (PI):}

The soil permeability is influenced by $\mathrm{Na}$, $\mathrm{Ca}, \mathrm{Mg}$ and $\mathrm{HCO} 3$ contents of the soil and affected by long term use of irrigation water. It is defined as follows (Ragunath 1987):

$$
+\mathrm{Na})
$$$$
\mathrm{PI}=(\mathrm{Na}+\text { sqrt HCO3 }) * 100 /(\mathrm{Ca}+\mathrm{Mg}
$$

Where the concentration of cations and anions are expressed in epm.

The value of PI of ground water samples of the study area range 32.3 to 46.7 which comes under class II (25-75\%) of Doneen chart (Domenico and Schwartz, 1990). therefore the ground water sample in the study area is in general suitable for irrigation purposes on the basis of US Salinity Diagram (1954).

\section{Hydro chemical Facies:}

Ground water quality is defined by the chemical constituents in the water and the chemical analysis data are helpful for determining the usefulness of ground water as a potable resource.

Rock Work, 2006 Software has been employed to calculate and plot the concentration of chemical constituents of ground water samples of both period using Piper and Stiff Diagrams. Piper Diagram, (Hem, 1985) is used to illustrate the major ions composition of ground water samples for both periods as shown in Figs. $(5,6)$. This diagram is particularly useful for detecting changes or trends in ground water chemistry across an area or through time (Sanders, 1998). Piper diagram shows that most samples are of mixed cations- $\mathrm{SO}_{4}$ type and samples 1, 2, 3 and 4 of $\mathrm{Ca}-\mathrm{HCO}_{3}$ type. Stiff Diagrams illustrates the water chemistry and shows similarities of shapes of samples 1, 2, 3, and 4. see Figs. $(7,8)$ This similarities indicates similar composition. Samples 5, 6, 7, 8, 9, and 10 also shows similarities of shape and in composition of mixed cations - SO4

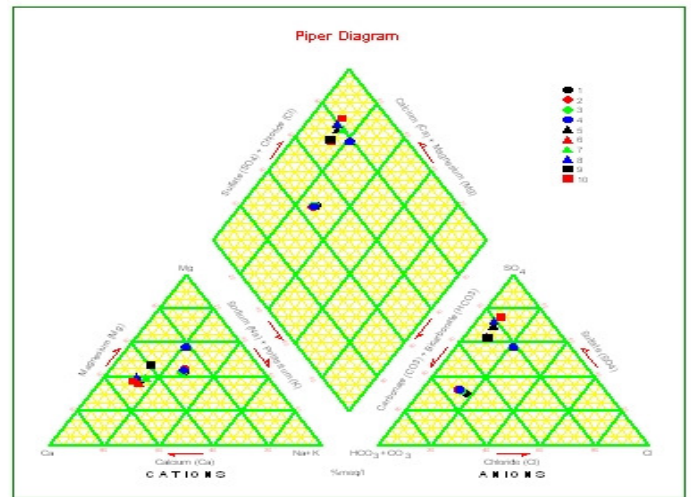

Fig. (5) Piper diagram for the period April 2007.

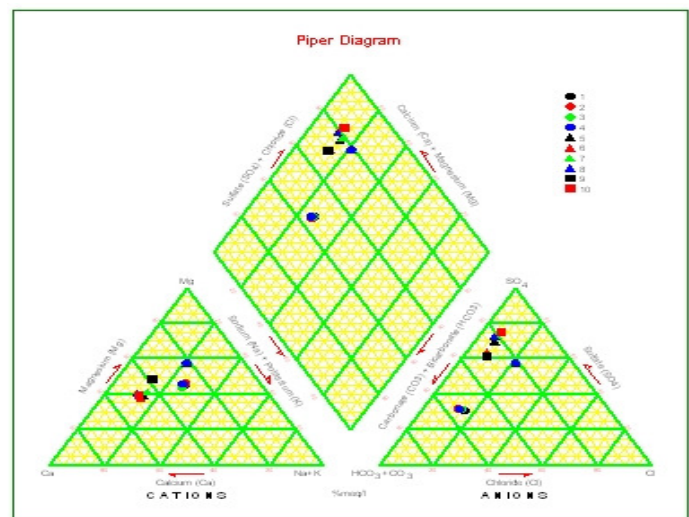

Fig. (6) Piper diagram for the period Nov. 2007. 


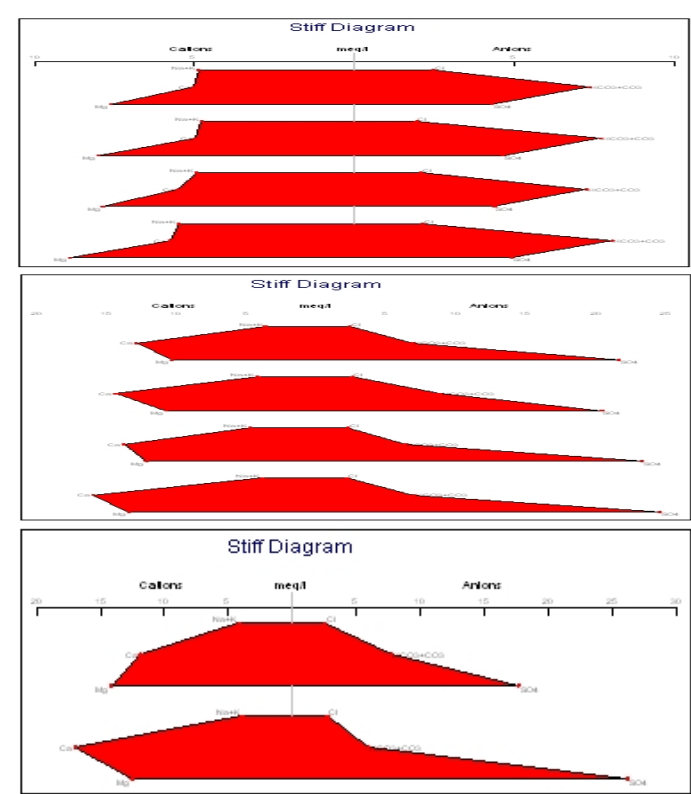

Fig. (7) Stiff Diagrams for the period April 2007

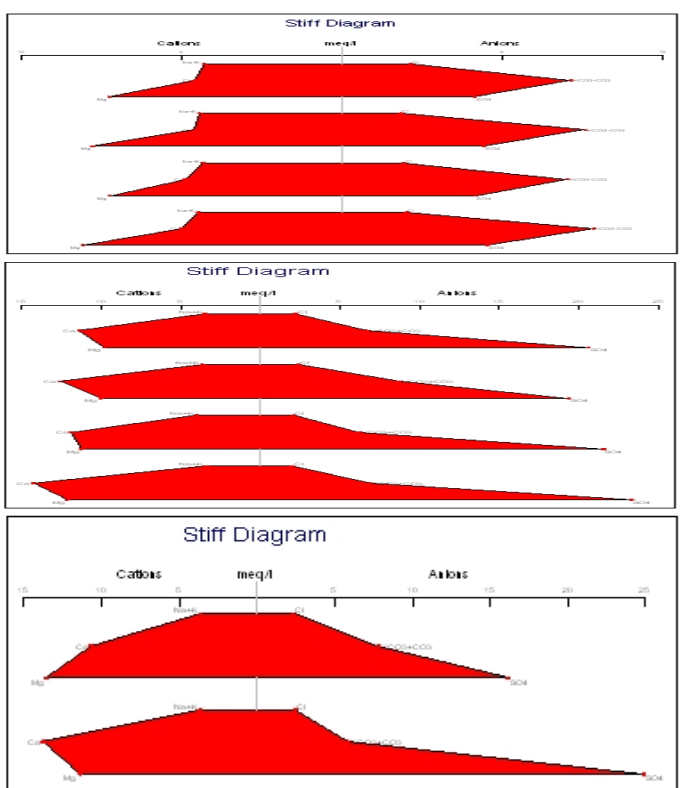

Fig. (8) Stiff Diagrams for the period Nov. 2007

\section{Conclusion}

This paper presents general guide lines for the variations in the chemical composition of ground water of the two periods of chemical analysis of groundwater samples and the suitability of ground water for domestics and agricultural purposes.

The chemical analysis of ground water reveals that the ground water is hard, fresh to saline and alkaline in nature. The $\mathrm{pH}$ value range between (7.1-7.63). The Ec value range from $1500 \mu$ mohs to $2659 \mu$ mohs. Total hardness value range from 757.1 $1388.6 \mathrm{mg} / \mathrm{l}$ and shows that the majority of ground water samples fall in the hard water category. TDS values range from $1450 \mathrm{mg} / \mathrm{l}$ to $3000 \mathrm{mg} / \mathrm{l}$.

Chemical parameters such as sodium percentage $(\mathrm{Na} \%)$, Sodium adsorption ratio (SAR), Permeability Index (PI) and saturation index with respect to calcite and gypsum (SI) were calculated, based on the major cation and anions analysis of ground water samples. The SAR value of ground water samples range from 2.88 to 6.82 which is fell in the low sodium class. This implies that no alkali hazard to the crops The $\mathrm{Na} \%$ values of ground water samples range from 29.37 to 46.07 . The $\mathrm{Na} \%$ of samples $(2,3,4$, $5,9,10)$ indicates that the ground water is good for irrigation while samples $(1,6,7,8)$ are permissible. From the residual sodium carbonate value of the ground water samples of the study area, it is observed that all samples are safe for irrigation. The value of PI of ground water samples of the study area range 32.3 to 46.7 . Therefore the ground water sample in the study area is in general suitable for irrigation purposes.

Piper and Stiff Diagrams also applied in this study using Rock Work 2006 software to show the trend of groundwater chemistry and chemical composition of groundwater samples of the study area.

High to very high salinity hazard shows that ground water in the south part of the study area can be used for plants having good salt tolerance and also restricts its suitability for irrigation.

The concentration of dissolved ions in ground water samples are generally governed by lithology, velocity and quantity of ground water flow, nature of geochemical reactions, solubility of salts and human activities. It is also shows slightly difference in concentration in cations and anions between the two periods of analysis due to the fluctuation change of water level along the groundwater column of the well and drainage system replenished groundwater.

Therefore the variations in the chemical composition of ground water of the two periods were caused by the interaction of ground water and host rocks in one hand and drainage system recharge and dissolution of surface pollutants during infiltrations and percolation of rainwater in the other hand. 
References:

Buday, T. and Jassim, S.Z. (1984). Final report and the regional geological survey of Iraq, Unpub. Report SOM. Library Vol.2 .Tectonic Frame work Baghdad.

Hem, J.D. (1985). Study and interpretation of the chemical characteristics of natural water, 2nd ed. U.S. Geological Survey water supply paper, 473,363 pp.

Karnath, K.R. (1987). Ground water assessment, development and management. Tata McGraw Hill, New Delhi, pp 720.

Krohte, N.C. and Bergeron, M.P. (1981). Hydrochemical facies in atertiary basin in the Milligan Canyon area, SW mountain, G.W. Vol 19, No 4, pp392399

Mohi-Alddin, R.M., Sissarian, V.R., Yousif, N.S., Amin, R.M. and Rofa, S.H. (1977). The rejional mapping of Mosul Tel-Afer area (SOM). Library report, Maghdad, Iraq.

Rainwater, K.H. and Thatches, L.L. (1960). Methods of collection and analysis of water samples. U.S. Geol. Surv. water supply paper 1454 .

Salama, R.b., Oho, C.J. and Fitzpatrick, R.W. (1999). Contributions of g.w.condition to soil and water salinization, Hydrogeology Journal, pp56-64 .

Sanders, L.L. (1998). a manual of field hydrogeology, Prentice -Hall,Inc.

Bhatt, K.B., Saklani, S. (1996). Hydrogeochemistry of the upper Ganges
River, India. J. Geol. Soc. India 48:171182.

Doneen, L.D. (1964). Notes on water quality in agriculture. Published as a water science and engineering paper 4001, Dept. of water science and Engineering. Univ. of California.

Raghunath, H.M. (1982). Ground Water, Vol. 456. Wiley Eastern Limited, New Delhi.

Raju, N.J. (2006). Hydrochemical parameters for assessment of ground water qyality in the upper Gunjanaeru River basin, Cuddapah District, Anhdra Pradesh, South India. Environ. Geo. Springer.pp 1067-1074.

Saleh, A., Al-Ruwaihm, F. Shehata, M. (1999). Hydrogeochemical processes operating within the main aquifers of Kuwait. J. Arid Environ. 42:195-209.

Schoeller, H. (1967). Qualitative evaluation of ground water resources. In: Methods and Techniques of ground water investigation and development. Water Research, Series-33, UNESCO, pp 4452.

US Salinity Laboratory (1954). Diagnosis and improvement of saline and alkali soil. Agricultural Handbook No. 60. USDA, $160 \mathrm{p}$.

WHO, (1984). Guide lines for drinking water quality, Vol. 1. Recommendation, World Health Organisation, Geneva, $130 \mathrm{p}$.

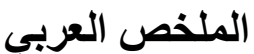

\section{تأثير مناطق التغذية و نظام التصريف على نوعية المياه الجوفية لمنطقة تلكيف شمال العراق}

\author{
طه حسين السالم، أسماء خالا جرجيس \\ مركز ألتحس النائي، قسم الجغرافية، جامعة الموصل، العراق
}

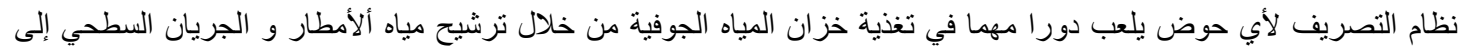

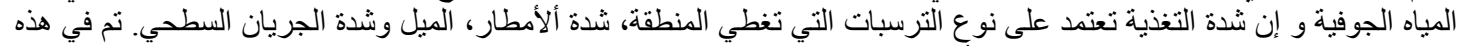

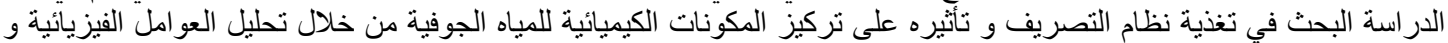

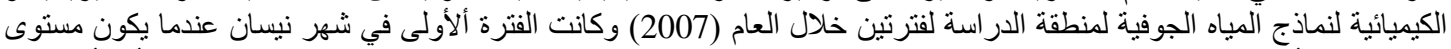

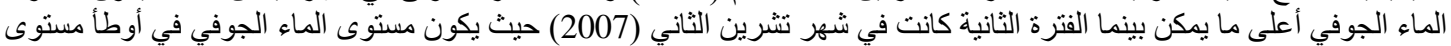

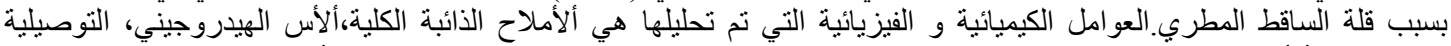

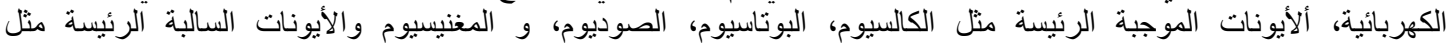

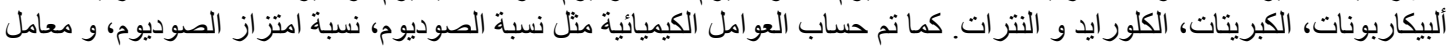

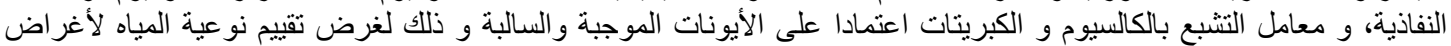

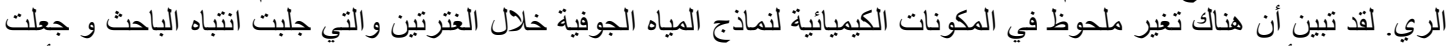

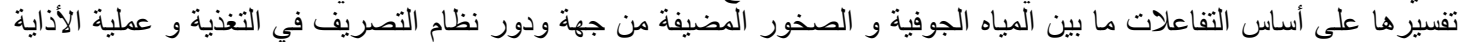

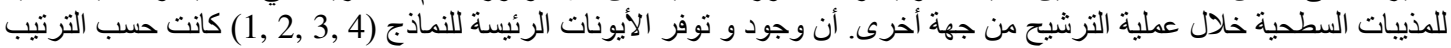

$\mathrm{Na}>\mathrm{Ca}>\mathrm{Mg}>\mathrm{K}=\mathrm{HCO}_{3}>\mathrm{SO}_{4}>\mathrm{Cl}>\mathrm{NO}_{3}$. بينما بقية النماذج الأخرى كانت حسب الترنيب التالي:

$\mathrm{Ca}>\mathrm{Na}>\mathrm{Mg}>\mathrm{K}=\mathrm{SO}_{4}>\mathrm{HCO}_{3}>\mathrm{Cl}>\mathrm{NO}_{3}$. 